\title{
Informacje o materiałach do badań nad oprawami książkowymi w spuściźnie ks. Leona Formanowicza w zasobie Archiwum Archidiecezjalnego w Gnieźnie
}

W magazynach Archiwum Archidiecezjalnego w Gnieźnie znajduje się wiele cennych zabytków piśmiennictwa, które w przeszłości wchodziły w skład zasobu kapituły kolegiackiej. Na przestrzeni wieków księgozbiór powiększył się m.in. o biblioteki prałatów i kanoników gnieźnieńskich oraz zakonów poddanych kasacie przez władze pruskie. Sam zasób wraz ze zwiększaniem swojej objętości był inwentaryzowany. Pierwszą próbę skatalogowania gnieźnieńskiego księgozbioru podjął się w latach trzydziestych XIX w. ks. Jan Zienkiewicz. Jego czterotomowe dzieło nie objęło jednak całości biblioteki. Pełnego zinwentaryzowania dokonał jego następca na stanowisku bibliotekarza w Bibliotece Katedralnej - ks. Jan Korytkowski ${ }^{1}$. Na przestrzeni lat katalog przestał odpowiadać faktycznie istniejącemu zasobowi, gdyż ten od śmierci Korytkowskiego znacznie się poszerzył. Próby kolejnego skatalogowania posiadanych starodruków podjęto się w 1968 r. ${ }^{2}$ Do końca 2012 r. skatalogowano niespełna dwa tys. woluminów.

$\mathrm{Z}$ nastaniem kolejnego roku prace $\mathrm{w}$ Archiwum Archidiecezjalnym w Gnieźnie podjął zespół pod kierownictwem dr. Piotra Pokory (Uniwersytet im. Adama Mickiewicza), który w ramach Narodowego Programu Rozwoju Humanistyki realizuje projekt Inwentaryzacji zasobu Biblioteki Katedralnej $w$ Gnieźnie $e^{3}$. Prowadzone prace inwentaryzacje mają na celu stworzenie nowoczesnego katalogu starodruków, który uwzględnia także informacje o ce-

${ }^{1}$ J. Rył, Biblioteka Katedralna w Gnieźnie w latach 1650-1975, nadbitka z czasopisma „Archiwa, Biblioteki i Muzea Kościelne" 1985, t. 51, s. 130-133.

${ }^{2}$ Tamże, s. 260.

${ }^{3}$ Projekt grantowy Inwentaryzacja zasobu Biblioteki Katedralnej w Gnieźnie finansowany jest z grantu NPRH MNiSW, nr 11H 12017981. 
chach fizycznych książek, co w przyszłości może się przyczynić do podjęcia dalszych badań nad zgromadzonym zasobem. Powstający katalog bez wątpienia da pewne podwaliny dla tegumentologów zajmujących się badaniem opraw książkowych.

W środowisku gnieźnieńskim tradycja badań nad oprawami książek sięga dwudziestolecia międzywojennego. W okresie tym bibliotekarzem i archiwistą kapitulnym był ks. Leon Formanowicz ${ }^{4}$. Wtedy też $\mathrm{w}$ bardzo szerokim zakresie poszerzał swoją wiedzę z zakresu bibliotekarstwa, spotykając się i wymieniając poglądy z innymi specjalistami w tej dziedzinie. Po otrzymaniu dekretu na stanowisko bibliotekarza podjął się prac mających na celu uporządkowanie zbiorów kapitulnych i seminaryjnych. Z biblioteki wyodrębnił zbiór 426 druków polskich XVI w. 5 , których katalog opublikował w 1930 r. ${ }^{6}$ Jeszcze większym dziełem były badania prowadzone nad gnieźnieńskim zbiorem inkunabułów, który wyodrębnił spośród druków wchodzących w skład księgozbioru kapitulnego i seminaryjnego. Podobnie jak w przypadku poloników, tak i dla ksiąg piętnastowiecznych sporządził katalog. Pierwszą jego część, zawierającą 407 pozycji, opublikował w 1939 r. ${ }^{7}$ Druga, bazująca na zapiskach ks. Formanowicza, została wydana przez ks. Juliana Wojtkowskiego w 1969 r. ${ }^{8}$ Sam Formanowicz nie doczekał wydania kolejnej części swojego dzieła. Jego żywot został przerwany przez hitlerowców, którzy najpierw umieścili go w obozie w Dachau, by 4 maja 1942 r. zagazować go w komorze gazowej w Hartheim k. Linzu ${ }^{9}$.

Pamięć o tym wybitnym naukowcu jest wciąż żywa. W Archiwum Archidiecezjalnym w Gnieźnie pozostała wielka spuścizna, świadcząca o szerokich zainteresowaniach ks. Formanowicza. Jeszcze przed podjęciem funkcji kustosza w bibliotece kapitulnej zasłynął jako kolekcjoner m.in. rzadkich druków, ekslibrisów i obrazków z wizerunkami świętych ${ }^{10}$. Ponadto zachowała się jego korespondencja prowadzona z osobami prywatnymi oraz z różnymi instytucjami. Jednak szczególnie cenne są teczki wchodzące w skład swoistej spuścizny naukowej. Ten nieposiadający sygnatury zespól, oczekujący na wnikliwe rozpoznanie, obejmuje 35 ponumerowanych teczek. Wśród nich

\footnotetext{
${ }^{4}$ Biografia: M. Formanowicz, Ksiadz Leon Formanowicz, Kanonik Katedry Prymasowskiej w Gnieźnie. Życie i praca (szkic biograficzny), http://www.formanowicz.pl/gost/biografie/ leon_formanowicz.pdf (dostęp 6 maja 2015 r.); zob. też Stownik pracowników książki polskiej, red. I. Treichel, t. 1, Warszawa-Łódź 1972, s. 229-300.

${ }^{5}$ M. Formanowicz, Ksiadz Leon Formanowicz, s. 5.

${ }^{6}$ L. Formanowicz, Katalog druków polskich XVI-go wieku Bibljoteki Kapitulnej w Gnieźnie, Poznań 1930.

${ }^{7}$ L. Formanowicz, Katalog inkunabułów Biblioteki Kapitulnej w Gnieźnie, z. I, Poznań 1939.

${ }^{8}$ J. Wojtkowski, Rekonstrukcja drugiego zeszytu katalogu inkunabutów Biblioteki Kapitulnej w Gnieźnie księdza Leona Formanowicza, „Archiwa, Biblioteki i Muzea Kościelne” 1985, t. 51, s. 81-124.

${ }^{9}$ M. Formanowicz, Ksiądz Leon Formanowicz, s. 11.

10 Tamże, s. 4.
} 


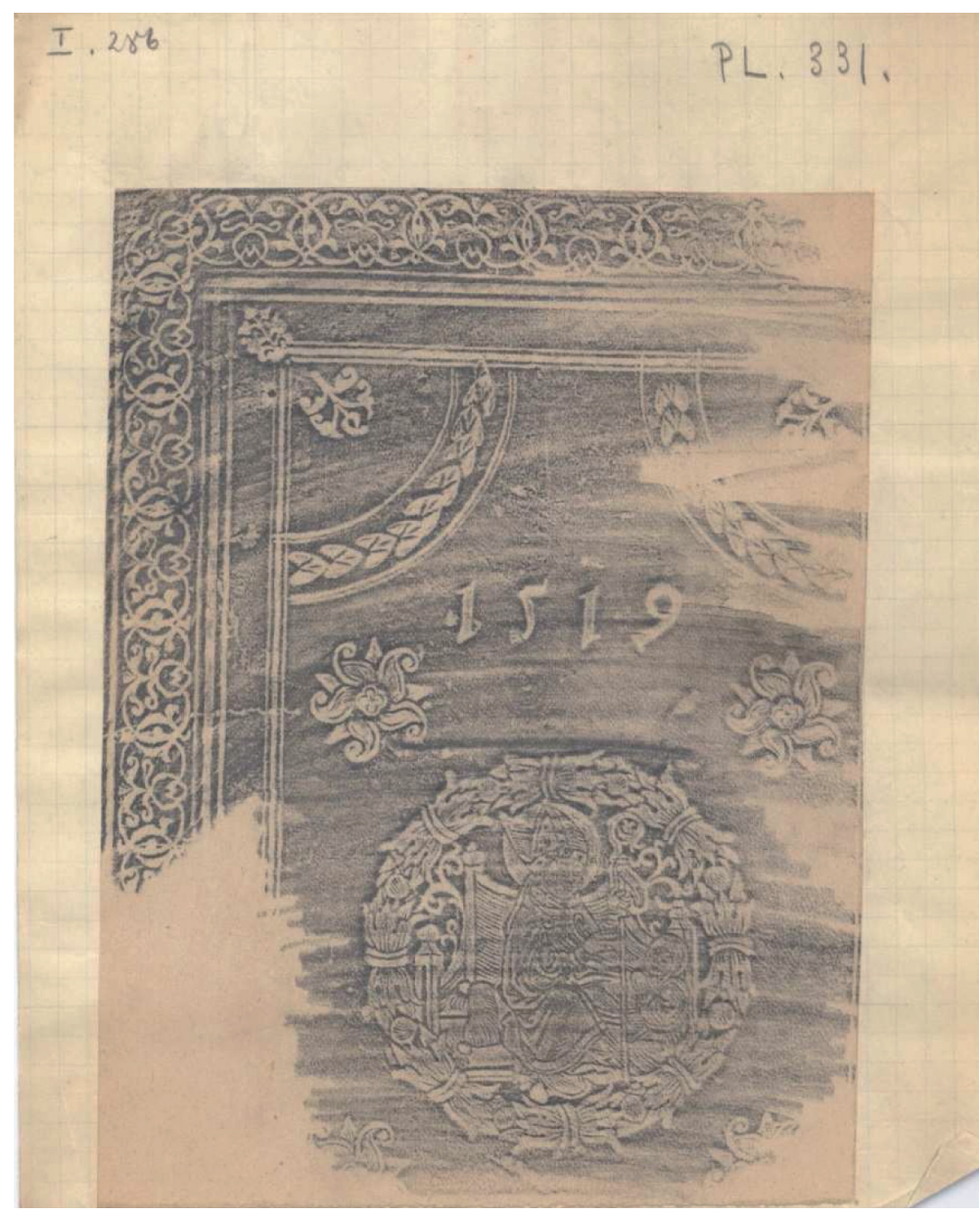

Fot. 1. Przykład odrysu. Teczka nr 6a, s. 2.

można znaleźć materiały dotyczące m.in.: kleru katedralnego, gnieźnieńskich kościołów, szkoły katedralnej, seminarium w Gnieźnie oraz gnieźnieńskiej biblioteki kapitulnej i seminaryjnej. Na pewno nie jest to zbiór kompletny, gdyż brakuje kilku z nich. Ostatnia została oznaczona liczbą 37. Większość otrzymała tytuły nadane przez ks. Formanowicza. Zapiski obejmujące jego badania nad inkunabułami i polonikami oraz ich oprawami znajdują się w sześciu teczkach ${ }^{11}$. Można w nich znaleźć blisko tysiąc stron z odrysami całych okładzin bądź ich poszczególnych elementów dekoracyjnych. Ponadto znajdują się tam informacje traktujące o miejscach oprawienia poszczególnych

11 Część z tych teczek była wzmiankowana w opracowaniu Biblioteka Katedralna w Gnieźnie w latach 1650-1975, gdzie autorka wymienia je w bibliografii, zob.: J. Rył, Biblioteka, s. 122. 
woluminów. Przy przeglądaniu teczek rzuca się w oczy ich uporządkowanie. $Z$ jednej strony, mamy do czynienia $\mathrm{z}$ ułożeniem materiału ze względu na miejsce powstania oprawy, a z drugiej z podziałem rzeczowym. Pierwsza z teczek, oznaczona numerem 6, nosi tytuł Oprawy wielkopolskie i poznańskie. Zawiera 242 strony. Teczka nr 6a nosi tytuł Oprawy matopolskie i krakowskie. Zawiera 58 stron. Teczka nr 7 nosi tytuł Oprawy oznaczone. Zawiera 239 stron. Są to odrysy opraw pochodzących z inkunabułów opisanych w pierwszym zeszycie Katalogu Inkunabutów. Teczka nr 8 nosi tytuł Biblioteka Kapitulna oprawy XV i XVI wieku. Zawiera 227 stron, na których widnieją odrysy z opraw rękopisów kapitulnych, ze zbioru poloników oraz inkunabułów. Teczka nr 9 nosi tytuł Ślask [i] Prusy Królewskie. Zawiera 64 strony. Ostatnia z teczek, oznaczona nr 14, jest najobszerniejsza. Nosi tytuł Oprawy inkunabułów Biblioteki Seminarium Duchownego w Gnieźnie. Zawiera 368 stron.

Materiały zawarte $\mathrm{w}$ powyższych teczkach zostały zeskanowane, dzięki czemu w najbliższym czasie powinny być udostępnione szerszemu gronu odbiorców. Pozostaje przy tym mieć nadzieję, że spuścizna ks. Formanowicza wraz z powstającym nowym katalogiem Biblioteki Katedralnej będzie impulsem do dalszych badań i prac z zakresu bibliologii czy też tegumentologii.

Mikołaj Macioszek

\title{
Informacje o materiałach do badań nad oprawami książkowymi w spuściźnie ks. Leona Formanowicza w zasobie Archiwum Archidiecezjalnego w Gnieźnie
}

\begin{abstract}
Streszczenie
Celem poniższego komunikatu jest poinformowanie o materiałach do badań nad oprawami inkunabułów i starodruków, znajdujących się w zbiorach Archiwum Archidiecezjalnego w Gnieźnie. Pochodzą one ze spuścizny ks. Leona Formanowicza, a z racji ich nieobecności w jakimkolwiek katalogu były praktycznie nieznane szerszemu gronu naukowców.
\end{abstract}

\section{Information on materials for researching book covers found in the heritage of father Leon Formanowicz in the collection of the Archdiocese of Gniezno Archive}

\begin{abstract}
The aim of the article is to provide information about materials for researching covers of incunables and old pints, which belong the Archdiocese of Gniezno Archive collection. They are a part of father Leon Formanowicz's heritage, and since they were not present in any catalog, they remained unknown to a broad academic audience.
\end{abstract}

